\section{SOCIAL STRUCTURE AND INTER-GROUP RELATIONS: A CASE STUDY OF A VILLAGE IN NEPAL TARAI}

\author{
Surendra Mishra
}

\section{Background of the Study}

Caste is defined variously. Hereditary membership, traditional occupation, commensality rules and purity are some of the major features of the caste system (Berreman 1972). It is culturally constructed and is the product of Hinduism. Castes are closed social groups: one may only marry within one' caste and the children of the marriage belong to the caste of their parents. Castes are hierarchically ranked on a purity pollution scale according to their traditional occupations. Castes are groups with a well developed life of their own, the membership where of, unlike that of voluntary associations and of classes, is determined not by selection but by birth. The status of a person depends not on his wealth but on the traditional importance of the caste in which he has the luck of being born (Ghurye 1969). According to Berreman (1972) castes are ranked endogamous division of society in which membership is hereditary and permanent (quoted by Sharma 2004: 129).

Anthropologically speaking, social structure is any enduring pattern or interrelationship of social elements/entities. In other words, it is more or less enduring pattern of social arrangements within a particular society, groups or social organization. In general, social structure is an arrangement of persons in institutionally controlled or defined relationships (Brown 1952).

Hierarchy is a ladder of command in which the lower rungs are encompassed in the higher ones in regular succession. Hierarchy in the caste system is the opposition of the pure and the impure: superiority and superior purity are identical. It is in this sense that, ideologically, distinction of purity is the foundation of status. (Dumont 1980). Nepal is a stratified society consisting of its hierarchically arranged caste-rankings. Caste has been recognized as unique socio-cultural phenomena. Nepalese caste rules normally prescribe isogamies for its members (Sharma 2004).

Nepal is a homeland for a number of ethnic/caste groups with different languages, religions and cultural traditions. There are over 100 distinct ethnic/caste groups who have been living side by side over the last 1500 years, maintaining separate yet related cultural traditions collectively known as "Nepali culture" today. This Nepali culture, in essence, is the combination of five distinct groups of people viz; the Hindu groups with caste origins, the Newars, the ethnic/tribal groups, the Muslims and others (Sikh, Bengali, Marwari and Christians). The Hindu caste groups comprise both the Hill and the Tarai groups. The social structure of the Hill caste Hindus is simple, in comparison to that of the Tarai. In the Tarai caste Hindus, there are more than 40 distinct cultural groups sharing mostly a common language and present a more complicated social structure than the hill caste Hindus (see Dahal 1995:150; Gunaratne 2002).

In the Nepali context, caste has become an institution rooted in the Hinduized way of life promoted by the state by nurturing customized laws (Hofer 2004). The religion and rituals prohibit the inclusion of those considered impure, lowly and untouchable into the social sphere. Caste, therefore, has in itself become an 
exclusionary social institution forcing those considered lower caste or outcaste people to live a life on the margins and struggle to survive on the crumbs. Ultimately, caste system has become a process of $\mathrm{so}_{\text {cial }}$ exclusion through which participation is restricted and claims to social opportunity denied (Kumar 1995:48).

It is evident that Nepali society is hierarchical and caste based where inter-groups harmony and cooperation also remains very strong. No doubt, conflict, clash of interest and competition are the essence of stratified society (See Caplan 1970). Many studies either by foreign scholars or native social scientists have revealed that there is extre me inequality between high caste and non caste ethnic groups; conflict between high caste Bahuns and untouchable caste. In spite of all these facts the bitter reality is that of multiple caste groups residing in a limited area for centuries past without any vital communal riot. It is a matter of interest to sociologist and anthropologists to look into the structure of the Nepali society and analyze the hierarchical caste system from functional point of view.

\section{The Study Area and Research Method}

This paper makes an attempt to demonstrate how the different caste groups in a rural village setting are interrelated with each other. More specifically, this paper attempts to deal with the political, social, economic, ritual and religious relationship between and among different caste groups in the Terai region.

The field work for this paper was carried out in 2003 in Mahamadpur Village Development Committee (VDC) Rautahat district. This village is heterogeneous in terms of caste composition. More than 25 caste groups were found residing in the study area. The numerically large caste group was Yadav and Bhedihar. A couple of SOciological/anthropological techniques were used to generate data for this study. The total population of the study area was 6553 , consisting 3367 male $(51.38 \%)$ and $3186(48.61 \%)$ females.

Table No.1 :Population in Mahamadpur VDC by caste Groups, 2001

\begin{tabular}{lcc}
\hline Caste Groups & Total Population & Percentage of the Total Population \\
\hline Yadav & 2197 & 33.52 \\
Kanu & 1060 & 17.17 \\
Kalwar & 410 & 6.25 \\
Teli & 485 & 7.40 \\
Chamar & 401 & 6.11 \\
Sonar & 371 & 5.66 \\
Kumhar & 192 & 2.92 \\
Tatma & 139 & 2.12 \\
Dhanuk & 122 & 1.86 \\
Barai & 119 & 1.81 \\
Bhedihar & 114 & 1.73 \\
Hajam & 112 & 1.70 \\
Koiri & 104 & 1.58 \\
Baniya & 88 & 1.34 \\
Malaha & 94 & 1.43 \\
Sanyasi & 85 & 1.29 \\
Bradhmin & 117 & 1.78 \\
Dom & 64 & 0.97 \\
Dusadh & 64 & 0.97 \\
Lohar & 61 & 0.93 \\
Dhobi & 57 & 0.86 \\
Mali & 58 & 0.88 \\
Kahar & 13 & 0.19 \\
Kurmi & 10 & 0.15 \\
Kayastha & 16 & 0.24 \\
\hline Total & $\mathbf{6 5 5 3}$ & $\mathbf{1 0 0 . 0 0}$ \\
\hline
\end{tabular}

Soucre: CBS. 2001

As stated above, there are many caste groups living in the study area (see table 1-1 for details) Yadav comprises of $33.1 \%$, the absolute majority of the population of the study area. The percentage of other caste groups consists of $16 \%$ of Kanu, $7.2 \%$ of 
Teli, $6.1 \%$ of Kalwar, $6.0 \%$ of Chamar, $5.5 \%$ of Sonar, $2.8 \%$ of Kumhar, 2.1 of Tatma, $1.9 \%$ Dhanuk, $1.8 \%$ of Barai, $1.7 \%$ of Bhedihar, $1.7 \%$ of Hajam and $1.6 \%$ of Koiri.

Fig 1: Hierarchy of various caste Groups in the Study Area: A General Model

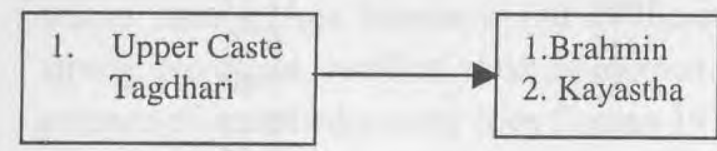

\section{Middle Caste Panichalane}

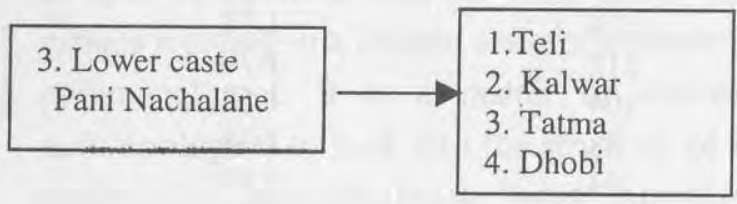

4. Lowest caste Pani Nachalne
1. Dusadh

2. Chamaar 3. Dom

1. Sanyasi
2. Yadav
3. Baniya
4. Malaha
5. Hajam
6. Lohar
7. Kumhar
8. Mali
9. Kanu
10. Barai
11. Sonar
12. Koiri
13. Dhanuk
14. Bhedihar
15. Kurmi
16. Kahar

1. Sanyasi

2. Yadav

4. Malaha

5. Hajam

6. Lohar

7. Kumha

8. Mali

9. Kanu

10. Barai

11. Sona

12. Koiri

14. Bhedihar

16. Kahar
The local distinguish four different hierarchical groupings of castes (see figure 1). As the general model indicates there are many caste groups in the middle caste whose water is accepted by all the caste groups. There are four low castes whose water in not accepted by middle and high caste groups. Likewise there are three lowest caste groups in the study area whose water in not accepted by lower, middle and high caste groups. Not only this the water from the lowest caste groups is not accepted between among the caste groups themselves.
Not all of the above mentioned caste groups are the indigenous inhabitants of this area. They migrated to this area from Bihar state in India many generations ago in search of work. They are Hindus and celebrate rituals and festivals of the Hindus. In general, the rituals, ceremony and festivals of all the Hindus are similar. The major festivals they celebrate are Dashain, Tihar, Holi, Chhatha. On the occasion of workship of Shiva and Satyanarayan Katha, they offer a big feast to all their fellow caste members in the village. They decorate their houses by painting and making pictures on the walls on the occasion of Tihar and marriage.

\section{Inter group Relations: Social}

Caste is one of the most important social institutions in the Nepal Tarai even today. Caste behaviours are deeply embedded in peoples 'values, reflecting hierarchy, endogamy, commensality and the other forms of the day to day interaction of people. Contacts of any kind touching, dining, sex and other social relations between castes of equal status are permissible or do not result in pollution. Mutual acceptability of cooked food, particularly rice and lentils denotes equal social status between caste groups. A member of the village community will marry only with the member of his own caste. Though 2 cases of inter caste marriage i.e. marriage between Tarai and hill caste group are reported in this VDC, these married couples are not accepted by the community even today. In other words, marriages across caste boundaries are regarded as deviations from an ideal norm of caste behaviour.

Even the type of meat consumed signifies social status; only mutton, pigeon and fish are consumed by the high caste Hindus. High caste Hindus are also not supposed to drink any kind of alcoholic beverages. All of these food items are defiling for them to maintain their ritual status. The pig raising is considered the most defiling job in this VDC. This job is done only by the lowest caste 
of the untouchable groups like Dom and Dushadh. Even today, the untouchable peoples mostly Dom and Halkhor are not allowed to enter the houses of the middle and high caste Hindus of the study area.

Nevertheless, most of the members of the village cooperate with each other on certain occasions such as weddings, funerals, festivals, worship of the village deity and thatching or building of a new house. For example, in the wedding ceremony of a Sanyasi and Yadav, most of the village members are invited for feast and Janti. Likewise, in the marriage ceremony of the Sonar group, other caste groups like Bhedihar, Lohar, Barai and Sanyasi actively participate in the marriage procession, eating and drinking. However, members of the higher caste such as Brahmin eat foods (except rice) appropriate to their caste which is prepared by persons of equal or higher status and served in an acceptable manner. Even during the funeral procession, most of the village people participate in the procession without much caste feeling. But in the funeral procession of lower caste and the lowest caste groups such as Dushadh, Chamar, Dom and Halkhor no high caste groups and few middle caste groups participate.

It is because of the high caste Hindu model which is operating smoothly in the village life over the years, some type of social mobility is gradually taking place in some groups of the Tarai. In the last one decade or so, with the decline of traditional occupation and participation in new types of economic activity, some groups like Teli and Kalwar are gradually upgrading their social status through wealth. These days, they are treated as the water acceptable community in the study area. They are now involved in different types of businesses.

\section{Inter group Relations: Economic}

On the basis of the survey of the study area, it can be said that most of the high caste groups such as the Maithili. Brahmain, Kayastha and middle caste groups like Yadav, Sanyasi, Bhedihar, Teli are the land owners and most of the untouchable castes are marginal landowners and landless labourers.

Even though involvement in agriculture is common to all castes from the Brahmin to the untouchable, certain kinds of occupation can be performed only by certain caste groups. Certain kinds of occupations are considered defiling for high caste Hindu groups. In other words, the economic disparity and caste specific occupations have resulted in economic interdependence between and among groups in the study area.

All the high caste, middle caste and the low caste groups come into contact with the Lohar (carpenter), Hajam (barber), Dhobi(washer man), Chamar (cobbler), and Dom (basket maker). Their services are considered indispensable in the village community. All of these groups come into contact with other groups usually in a non ritual context, mostly economic but there are exceptions. For example the Hajams, Lohars and Chamars, services are essential in certain ritual and social occasions of the community.

Some of the caste groups of the study area provide their services in the traditional Jajamani system. Jajamani is a service rendered by a person to his client in cash or kind or both. Two types of Jajamani services are prevalent in the study area.

1. Services provided by the Maithil Brahmin Priests to their clients, particularly the high caste, middle caste and the lower caste Hindu groups except the lowest caste groups such as Chamar, Dushadh, Dom and Halkhor. 
2. Services provided by the lowest untouchable castes and Middle castes to the higher, middle and lower caste. In return of their services, these groups are provided grains on an annual contract basis.

Services provided by the low castes to the members of their own caste and high and middle castes (known as Jajmani) is locally known as Sali system. The caste groups who are engaged in Sali system in the study area are Hajam, Lohar, and Chamar.

\section{Hajam}

By providing their traditional services of shaving, a Hajam is paid $20 \mathrm{~kg}$ of paddy annually per person. A Hajam visits the households of his client once or twice in a week. The wives of Hajam also visit their client's households during delivery, Bratbandh and death ritual to cut the nails (of hands and feet) of women. In the study area, almost every Hajam household has $30-40$ clients and collects 6-8 quintals of paddy per annum. They also get cloth, grain, and money on special occasions such as bratbandh (sacred thread wearing ceremony), marriage, mundon (hair shaving ceremony), and death.

\section{Lohar}

The Lohar is a carpenter in the local context. For their services, they charge cash or sometimes grains on a piece work basis. Unlike hill group, the Lohar also does the iron work and contract their clients on a fixed amount of grains to be paid annually. They charge $40 \mathrm{k}$. g. of grains per plough per household.

\section{Chamar}

The Chamars are also engaged in the Sali system. Each Chamar household is paid $5 \mathrm{k.g}$. of grains annually for disposing the dead animals. Every household who has animals like ox, cow, buffalo pay this grains annually whether an animal dies or not. The Chamar ensures his clients that his services are guaranteed when it is needed. A Chamar household has 20-25 households as clients and collects about a quintal of grain annually from every household. Now a days the Sali system is gradually changing. The Chamars are not paid grains annually; instead they are paid in cash on the basis of the dead animals. They charge NRs 50 to 100 per dead animal for disposing the carcass.

The Chamars play musical bands in different rituals and festivals occasions, for which they are paid cash and grains.

The Maithil Brahmins provide their priestly services both from whom they accept water and some of the middle castes from whom they do not accept water. In this respect, they can be treated just like the barber and the carpenter. However, the basic difference between them is that the Brahmins are not paid annually; they are paid on piece-work basis for their services. Moreover, the amount to be paid is not fixed; it depends upon the economic status as well as the generosity of the clients. Nevertheless, the priest is an important member of the village organization and maintains good socio-economic relationship to the members of almost all the water acceptable caste groups.

The other form of economic interrelationship and economic interdependence is the source of credit to cope up with the food shortage and to meet the household's incidental and contingent expenses. A number of poor farmers in this VDC take loans.

The sources of institutional credit in the study area are the local landlords such as Brahmin, Sanjasi, Bhedihar, and Yadav. Loan is taken in two forms: cash and grain. The interest rate is high, ranging from 48 to 60 percent per annum. Normally, the loan taken in grains must be repaid in grains only with high interest. As many farmers are landholders in the study area, they repay loans by 
working in the fields of landlords either in planting or harvesting seasons. Most of the loans are borrowed against gold, silver and land as surety.

Some poor people also work as ploughmen or agricultural labourers as desired by the landlords because they have been provided some land to subsist themselves without rent. However, the landlord also provides them their daily wage (Rs. 50/- and 2 meals per day for working from the morning to the evening) while working. They are also free to work in other s land when there is no work in the house of the landlord. In other words, labour scarcity is creating economic interdependence between landless farmers and the landlords.

\section{Inter-group Relations: Political}

The Tarai as a whole was considered sensitive politically by the ruling elites of Kathmandu throughout history. Because of their close affinity with India and the Indian people, the Tarai people, particularly the Indian origin people were mistrusted and wherever possible they were excluded in the national politics of Nepal. For the first time, King Mahendra realized this political sensitivity of the Tarai people and gradually incorporated the Tarai indigenous groups as well as other caste groups into the mainstream of the National politics of Nepal. King Mahendra encouraged directly or indirectly to settle down the hill people into the Nepal Tarai to harmonize the process of "Nepalization" and national integration so that no hatred feelings could be developed towards each other, i.e. between the hill and the Tarai people.

The Tarai people are coming more and more closer to the hill people but also engage in debate about participating in the national politics of regionalism which also harbouring some sort of hatred feeling towards one another. Moreover, factions within Tarai groups i.e. between high castes and low casts and Yadavs verses other are also on the rise in recent years. The prominent groups in the Tarai politics today are the Yadavs and the Muslims.

In Tarai politics, Rautahat district is no exception in regard to political power becoming the privilege of the economically betteroff people. Rauthat district is controlled by Yadavs-over the las four decades or so. The district president was Yadav and one of the members of the parliament in the lower house was from Yadav community in this district.

One of the important qualities of the Yadav community is that they always form a close-knit group vis-à-vis other castes. They possess wealth and also demonstrate muscles to take control of politics. The Yadavs have been the successful political leader in this VDC from the time of Panchayat period. There are many reasons why Yadav could hold the active leadership in this VDC. For instance, Mahamadpur VDC is composed of diverse caste groups and the number of highest and many of the lower castes are landless. These landless and marginal hand holding people always need financial and other kinds of moral support services. These support services are provided to the people mostly by Yadavs of the area.

The Yadavs of this VDC are rich compared to other caste groups. They are helpful. They not only help others in the village but also at the district level. They go with the people to district headquarters and help there wherever needed. The local people therefore trust them for economic and social security.

Nevertheless, in the village election, different castes hold the positions of ward chairman such as Bhedihar, Sonar, Chamar, Yadav, Barai. But the position of VDC chairman is held by the Yadav only. During the election period, though there is caste feeling, people cast vote considering the party after the restoration of democracy. In other words, inter-groups relationship is gradually increasing in the larger political context of the society. The people 
help and try to understand each other to make the village environment peaceful and developed.

\section{Inter-group Relations: Ritual and Religious Context}

Though there is an overlap of social and religion activities, there are distinct caste services which are indispensable in certain religious and ritual occasions of the village life. Such groups who provide their religious services are the barbers, Brahmins, goldsmith (sonar) and Chamars.

The barbers' services are necessary in most of the ritual occasions of middle caste, lower caste and the high caste Hindu groups. A barber acts as a ritual purifier during birth, marriage and death. Shaving is required for a man in many ritual occasions such as 'Upanayan' ceremony, death of any member of a family, during the ancestor worship and at the time when a person takes part in a ceremony. During delivery, a woman is ritually purified on the $6^{\text {th }}$ day when her nails of hands and feet are cut and also after the death of any member of a family her nails are cut down on the 10th day of the death by a Hajam woman.

A Maithil Brahmin is respected in the ritual context even if he may be very poor. In every ritual such as birth, marriage, Upanayan, construction of a new house, worship of any god, new vehicle and death, all castes, expect the lowest caste group of the Tarai invite the Brahmin. The goldsmiths (sonar) are invited to ritually pierce the ears of young boys and girls of high caste Hindus. Similarly, the Chamars play with their drums in many rituals occasions such as the Mundan (hair cutting ritual) Upanayan, worshipping of the village deity.

There are many caste specific festivals and ritual occasions such as the "Madhusrawani" by the Maithil girls in the month of Shrawan, and the worship of Salesh by the Dushadh in the month of the
Kartik. On the other hand, there are certain festivals and rituals which are celebrated by most of the caste group of the village community. Some of the common Tarai Hindu festivals and rituals are listed, where inter-group relations can be observed distinctly.

\section{Chaurchand}

Almost all caste groups celebrate chaurchand in the month of Bhadra. They worship the moon by offering rice pudding, fruits and curd. On this occasion, they also invite close relatives and friends for a feast at home.

\section{Durga Puja}

Durga puja is also widely celebrated by the Tarai caste Hindu groups in the month of Asoj or Kartik (Oct/ Nov). Unlike the hill people, who put tika on their forehead and move to the households of relatives for tika, blessings and feast, the Tarai people worship Durga only to get tika and blessing from the priest (Brahmin). They worship goddess Durga by offering sweets and by sacrificing goats and pigeon. The people of other castes of this VDC receive jamara from the Maithil Brahmin- the local priest.

\section{Tihar}

All the caste groups celebrate the Tihar festival by worshipping the goddess Laxmi in the month of Kartik. However, the Teli, Baniya and Kalwar (all of them are the business groups) celebrate this festival lavishly.

The Kayasthya worship Chitra Gupta (who is believed to write peoples fate during birth) in Tihar while worshipping inkpots and pens. The festival follows a feast, inviting the relations and neighbors. 


\section{Chhath}

All the Tarai caste groups celebrate this festival in the month of Kartik. The people celebrate this festival for two days. On the first day they worship the setting Sun god and on the second day they worship the rising sun god in the morning.

In brief, a Village Development Committee (VDC) in the Tarai is not necessarily a homogenous community today. It shows considerable diversity in terms of language, religion and culture. Though there is tremendous diversity among the Tarai caste groups, they, however, co-exist together because of the following economic factors:

1. In a board sense, a single culture area in the Tarai constitutes a region in the sense of a common language. The people speaking the same language have certain degree of commonalities which bind them together. For example, the Maithil Brahmins and the untouchables speaking the same language have certain culture forms in common, though they pace themselves in two extremes in the hierarchical model of the Hindu caste structure.

2. It is also difficult to isolate a particular culture trait as social, economic or religious as one trait complement the other in an organic, functional character of the society. Nevertheless, the other most important binding factor is the economy of the people itself. Historically, the economy of the Tarai is governed by two groups of people, the big landlords and the peasants or landless farmers. This economic model is operating up to now. Similarly, certain caste groups are permitted to do only certain type of caste specific occupation. In other words, the economic disparity and caste specific occupations force people to line together for survival
3. Historically, the Hindu caste hierarchical structure has remained as a model to co-exit. The various caste groups have remained as a basis of social interaction among the majority of the Tarai people.

4. Rituals and festivals which are celebrated locally by the people, always help to minimize the structural cleavages between and among groups.

5. Finally, the Tarai social structure is little dynamic as a whole Over the last 200 years of the settlement history of the Tarai, only few groups like Teli, Sudhi, and Kalwar are able to raise their social position from the water unacceptable group. The nature of struggle is economic rather than social. As these groups earned good money in the local context through business, and started sending their children to better schools these socio-economic mechanisms have helped them to raise their social status as water accepted community. In this VDC the local people, except the Maithil Brahman started accepting water from these caste groups only during the last decade or so.

\section{Conclusion}

The Tarai villages in general and Mahamadpur village in particular are not the homogeneous communities. However, this Village is more homogenous in its social structure. If we analyze the socially defined boundaries of kinship, caste, ethnicity, language, economic condition, duration of stay and religious values, this village shares many of these features in common. Though a clear account of the history of many of the caste groups under study is not available, it is however clear that most of the caste group under study came from the neighbouring states of Bihar in India. All of the caste groups in the study area are Hindus. They celebrate Hindu festivals 
and worship Hindu gods and goddesses on different occasions. They speak local Maithili language. Their marriage and kinship patterns are similar and they are closely tied with the Tarai Hindu caste, hierarchical model.

Though the caste solidarity is more pronounced among the caste groups, politics is controlled more by the Yadav in the study area. The Yadavs are economically well off and also stressing their horizontal tiller across the village boundaries.

All the caste groups in the study area have harmonious social relationship. They participate in feasts of each other, worship of village deities, marriage ceremony and death ritual. The social solidarity is seen on the occasion of Holi festival in which all the caste groups irrespective of political ideology and local personal differences gather at a public place and exchange their best wishes by distributing red colour and cardamom, nuts and betel.

\section{References cited}

Berreman, Gerald D. 1972. Hindus of the Himalayas, India: Oxford University.

Beteille, Andre. 1966. Caste, Class and Power: Changing Patterns of Stratification in a Tangore Village, India: Oxford University.

Caplan, Lionel. 1972. Land and Social Change in East Nepal: A study of Hindu-tribal Relations, London: Routledge and Kegan Paul Limited.

Dahal, D.R. 2003. Hindu Nationalism and Untouchable Reform: The Status of Dalits in Nepali Society. A Paper Presented at The Agenda of Transformation: Inclusion in Nepali Democracy Organized by the Social Science Baha, Kathmandu.

Dahal, D.R.1995. State Leadership and Politics in Nepal by Dhruba Kumar, Kathmandu: CNAS.

Dumont, L.1988. Homo Hierarchicus: The Caste System in India and its Implications. Delhi: Oxford University Press.
Ghurye, G.S. 1969. Features of the Caste System, Caste and Race in India, Popular Parakashan, Bombay.

Gunaratne, Arjun. 2002. Many Tongues, One People: The Making of Tharu Identity in Nepal. Ithaca and London: Cornell University Press.

Kumar, Dhruba. 1995. State Leadership and Politics in Nepal, CNAS, KTM.

Sharma, Prayag Raj. 2004. The State and Society in Nepal: Historical Foundations and Contemporary Trends, Lalitpur: Himal Books. 